\title{
KONDISI SOSIAL EKONOMI MASYARAKAT SEKITAR HUTAN LINDUNG BUKIT DAUN DI BENGKULU
}

\author{
Gunggung Senoaji \\ Jurusan Kehutanan Fakultas Pertanian Universitas Bengkulu \\ Email : senoaji1211@gmail.com
}

\begin{abstract}
ABSTRAK. Penelitian ini bertujuan untuk mengetahui kondisi sosial ekonomi masyarakat sekitar hutan lindung di Bengkulu. Metode penelitiannya adalah metode survey dengan beberapa teknik PRA. Penelitian di lakukan di Desa Air Lanang, Bengkulu. Data yang dikumpulkan dengan pengamatan dan wawancara mendalam kemudian dianalisis dengan analisis dekriptif kualitatif dan kuantitatif. Desa Air lanang memiliki luas 289,25 ha dengan jumlah penduduknya sebanyak 1.460 jiwa (285 KK). Sebagian besar penduduknya bermata pencaharian sebagai petani dengan tingkat pendidikan yang rendah. Rata-rata luas lahan garapannya adalah 2,5 hektar, dimana 1,6 hektar berada di dalam kawasan hutan lindung. Komoditas utamanya adalah kopi, dengan produksi sebesar $500 \mathrm{~kg} / \mathrm{ha} / \mathrm{tahun}$. Jarak rata-rata dari desa ke kebun di hutan lindung adalah 2,6 km. Pendapatan masyarakat sangat tergantung kepada harga kopi yang fluktuasi harganya cukup tinggi. Jika harga kopi dibawah Rp. 6000, mereka termasuk kedalam katagori masyarakat yang berada di bawah garis kemiskinan. Saat ini pengelolaan kawasan hutan lindung oleh masyarakat menggunakan konsep hutan kemasyarakatan, yang ternyata belum bisa mengoptimalkan fungsi hutan lindung.
\end{abstract}

Kata kunci : Sosial, ekonomi, masyarakat sekitar hutan, Hutan Lindung

\section{THE SOCIAL ECONOMIC CONDITION OF COMMUNITY LIVING AROUND THE BUKIT DAUN PROTECTED FOREST IN BENGKULU}

ABSTRACT. The objective of this research was to identify of social economic condition of community living around forest in Bengkulu. The technique of Participatory Rural Appraisal survey was employed in the study. Data were collected by conducting participating observations and open in-depth interviews in the Desa Air Lanang, Bengkulu, Data and information were analyzed by qualitative and quantitative analysis. The result of this research showed that population of Desa Air Lanang were 1.460 persons (285 families). The main livelihoods were farming with a low level of formal education. Their average land is 2.5 hectares, 1.6 hectares is located in the area of protected forest. Coffee is the main commodity, with production of $500 \mathrm{~kg} / \mathrm{ha} /$ year. Average distance village to the garden in the protected forest is $2.6 \mathrm{~km}$. Income people are depending on the price of coffee price. However, if price of coffe less Rp. 6000, they was under the poverty line. Currently, the management of forest protected areas by using the 
concept of forest communities, that can not optimize the function of protected forests.

Key Word : Social, economic, forest community, protected forest

\section{PENDAHULUAN}

Hutan merupakan sumberdaya alam yang mempunyai peranan penting bagi kehidupan manusia karena mampu menghasilkan barang dan jasa serta dapat menciptakan kesetabilan lingkungan (Steinlin, H. 1988). Sejalan dengan waktu, hutan yang semula dianggap tidak akan habis berangsur-angsur mulai berkurang. Banyak lahan hutan digunakan untuk kepentingan lain, seperti pertanian, perkebunan, pemukiman, industri dan penggunaan lainnya. Di Provinsi Bengkulu luas kawasan hutan yang telah beralih fungsi menjadi lahan pertanian, perkebunan, pemukiman, tanah kosong, dan kebun campuran mencapai 286.777 hektar atau sekitar $31,14 \%$ dari luas total hutan yang ada (Pemerintah Propinsi Bengkulu, 2008).

Permasalahan konversi hutan ini berakar dari pertambahan penduduk yang terus meningkat. Pertambahan penduduk menuntut tercukupinya kebutuhan pangan, kebutuhan kayu bakar, kebutuhan kayu pertukangan, dan tempat pemukiman. Di lain pihak lahan pertanian sebagai penghasil pangan luasannya terbatas, sehingga alternatif utama untuk pemenuhan kebutuhan pangan adalah mengkonversi lahan hutan menjadi lahan pertanian (Simon, 2001). Keterbatasan lahan yang dimiliki oleh masyarakat di sekitar hutan akan berakibat pada kondisi hutan di sekelilingnya. Mereka akan menggantungkan hidupnya pada hutan yang ada di sekeliling pemukimannya guna memenuhi kebutuhan hidup yang terus meningkat. Tanpa pengelolaan yang tepat, hal seperti ini merupakan ancaman bagi keberadaan dan kelestarian hutan, serta dapat menurunkan fungsi ${ }^{1}$ dari peruntukan hutan tersebut.

Sejalan dengan paradigma baru pembangunan kehutanan ${ }^{2}$ yang mengarah pada terwujudnya kelestarian hutan sebagai sistem penyangga kehidupan, memperkuat ekonomi rakyat, mendukung perekonomian nasional bagi

\footnotetext{
${ }^{1}$ Undang-Undang No. 41 Tahun 1999 tentang Kehutanan menjelaskan bahwa hutan memiliki tiga fungsi, yaitu : (1) perlindungan sistem penyangga kehidupan untuk mengatur tata air, mencegah banjir, mengendalikan erosi, dan menjaga kesuburan tanah; (2) pengawetan dan pelestarian keanekaragaman tumbuhan dan satwa serta ekosistemnya; (3) memproduksi hasil hutan.

2 Paradigma pembangunan kehutanan telah mengalami pergeseran yang semula bertumpu pada "timber based management" menjadi pendekatan ekosistem: " resource based management" yang berbasis pada " forest community based development (FCBD)". Departemen Kehutanan sejak tahun 2002 telah menetapkan 5 (lima) kebijakan prioritas, yaitu pemberantasan illegal logging, pengendalian kebakaran hutan, rehabilitasi dan konservasi SDA, restrukturisasi industri kehutanan, dan percepatan desentralisasi kehutanan. Implementasi lima kebijakan prioritas tersebut dilaksanakan melalui program-program pembangunan kehutanan dengan pendekatan paradigma "sosial forestry " (Nur Hidayat dan Suparno : "Pengembangan Kelompok Masyarakat Produktif Mandiri Berbasis Pembangunan Kehutanan", Pusat Penyuluhan Departemen Kehutanan, 2002).
} 
kesejahteraan rakyat, serta meningkatkan partisipasi masyarakat dalam pembangunan kehutanan, maka kebijakan pengelolaan dan pemanfaatan hutan haruslah betul-betul melibatkan dan menyentuh langsung masyarakat, khususnya masyarakat yang tinggal di sekitar hutan. $\operatorname{Simon}^{3}$ (2000) menjelaskan bahwa pada waktu lampau, pengelolaan hutan menekankan pada pendekatan teknik dan ekonomi. Namun sekarang rimbawan dituntut untuk menfokuskan masalah sosial sebagai bagian dari proses pengelolaan hutan yang lestari. Memecahkan masalah sosial memerlukan sebuah pemahaman terhadap nilai-nilai yang dipegang oleh masyarakat dan partisipasi dari kelompok masyarakat kunci dalam membuat keputusan tentang pengelolaan hutan. Sekarang ini kunci keberhasilan pengelolaan sumberdaya hutan ditentukan oleh keberhasilannya dalam memecahkan masalah sosial ekonomi masyarakat. Gagal dalam pemecahan masalah ekonomi masyarakat, akan gagal pula dalam upaya pengelolaan hutan (Simon, 2001).

Salah satu konsep pengelolaan hutan yang melibatkan peran masyarakat adalah program hutan kemasyarakatan. Departemen Kehutanan (2002) menjelaskan bahwa hutan kemasyarakatan adalah sistem pengelolaan hutan berdasarkan fungsinya dengan mengikutsertakan masyarakat. Kegiatan hutan kemasyarakatan ini diprioritaskan pada daerah-daerah hutan yang mendapat tekanan penduduk cukup tinggi. Kawasan hutan yang dapat ditetapkan untuk kegiatan hutan kemasyarakatan adalah kawasan hutan lindung dan atau hutan produksi yang kritis dan perlu direhabilitasi dan belum dibebani hak-hak lain. Program hutan kemasyarakatan mulai digulirkan sejak tahun 1995, namun di Propinsi Bengkulu ${ }^{4}$ baru dimulai pada tahun 1999. Salah satu daerah yang mendapat program pengembangan hutan kemasyarakatan adalah Desa Air Lanang yang berbatasan dengan Hutan Lindung Bukit Daun.

Pengaruh kondisi sosial ekonomi masyarakat desa hutan terhadap hutannya mencakup berbagai kehidupan, berupa ketergantungan ekonomi, kawasan buru untuk kebutuhan protein, areal perladangan dan perkebunan, bahan bangunan, dan fungsi lain yang berhubungan dengan kelembagaan sosial tradisional di masyarakat. Simon (2000) menyimpulkan bahwa kondisi sosial ekonomi masyarakat di sekitar hutan merupakan variabel yang perlu diperhitungkan dalam merumuskan tujuan pengelolaan hutan. Selanjutnya Subaktini, et al (2002) menjelaskan bahwa karakteristik sosial ekonomi budaya sangat berpengaruh dalam pengelolaan hutan. Oleh karena itu pemahaman tentang kondisi sosial

\footnotetext{
${ }^{3}$ Hasanu Simon, "Hutan Jati dan Kemakmuran" Bigraf Publishing hal 61. Pengelolaan hutan pada periode konvensional (timber manajemen) tujuan utamanya adalah produksi kayu yang maksimal dengan mengembangkan teknik silvikultur pemulian pohon dan teknik pengaturan hasil; pada saat itu kondisi sosial ekonomi masyarakat belum mempunyai pengaruh nyata terhadap hutan karena luas lahan untuk setiap keluarga masih mencukupi kebutuhan dasarnya.

${ }^{4}$ Program Hutan Kemasyarakatan di Bengkulu, dimulai pada tahun 1999-2004 dibawah koordinasi Balai Rehabilitasi Lahan dan Konservasi Tanah Ketahun, Bengkulu, Departemen Kehutanan; yang pelaksanaannya dilakukan di 7 desa di sekitar hutan lindung Bukit Daun, Kabupaten Rejang Lebong (sekarang Kabupaten Kepahiang dan Rejang Lebong).
} 
ekonomi masyarakat di sekitar hutan perlu diketahui untuk mengetahui sejauh mana pengaruh keberadaan masyarakat terhadap kualitas hutannya. Mengetahui kondisi sosial ekonomi dan budaya masyarakat di sekitar hutan merupakan suatu kajian yang perlu dilakukan untuk mendapatkan informasi tentang hubungan dan pengaruh keberadaan hutan serta fungsinya terhadap kehidupan masyarakat di sekitar hutannya termasuk untuk membuat rencana atau evaluasi kegiatan pengelolaan hutan.

\section{METODE}

Kegiatan penelitian dimaksudkan untuk memperoleh informasi tentang kondisi sosial ekonomi masyarakat sekitar hutan. Penelitian dilakukan di Desa Air Lanang, Kecamatan Curup Selatan, Kabupaten Rejang Lebong. Penelitian ini dilakukan pada bulan Maret - Oktober 2008.

Metode dasar yang digunakan dalam penelitian ini adalah metode survey deskriptif ${ }^{5}$ dengan pendekatan beberapa teknik PRA ${ }^{6}$ (Participatory Rural Appraisa) seperti : pemetaan kawasan, penelusuran lokasi, sketsa kebun, analisis mata pencaharian, dan wawancara semi terstruktur. Jenis data yang dikumpulkan adalah data primer dan data skunder. Pengumpulan data primer dilakukan secara partisipatif melalui wawancara langsung dengan masyarakat. Data skunder diperoleh dari laporan-laporan penelitian sebelumnya, data monografi desa, dan literatur lain yang mendukung.

Pemilihan responden masyarakat dilakukan dengan accidental sampling, yaitu pemilihan responden sebagai sampel dilakukan dengan cara memilih secara langsung masyarakat yang ditemui di lokasi penelitian. Banyaknya masyarakat yang akan dijadikan responden adalah $10 \%$ dari kepala keluarga yang ada di desa ini. Menurut Arikunto (2003) besarnya sampel penelitian sosial tergantung dari jumlah populasi yang ada, jika populasi kurang dari seratus maka sebaiknya diambil seluruhnya dan jika populasinya lebih dari seratus, sampel yang diambil antara $10 \%-20 \%$. Jumlah kepala keluarga di desa ini adalah $285 \mathrm{KK}$, karena itu jumlah respondennya adalah 30 KK (pembulatan ke atas dari 28,5).

Teknik pemetaan (mapping) adalah teknik PRA untuk menggambarkan keadaan wilayah desa dan lingkungannya. Informasi yang diperoleh dari pemetaan adalah kondisi umum lingkungan desa seperti sumber daya, sarana dan prasarana, keadaan fisik lingkungan desa, dan kondisi khusus yang dinginkan. Teknik penelusuran wilayah (transek) adalah teknik PRA untuk menggali informasi melalui pengamatan langsung ke lapangan dengan cara berjalan menelusuri wilayah desa dengan mengikuti lintasan yang disiapkan. Informasi yang dapat

\footnotetext{
${ }^{5}$ Mantra (2008) "Filsafat Penelitian dan Metode Penelitian Sosial". Penelitian deskriptif bertujuan untuk mendeskripsikan atau melukiskan realitas sosial yang ada di masyarakat.

6 Daniel et all (2006) "PRA (Participatory Rural Appraisa)". Metode PRA merupakan suatu metode penelitian yang dapat digunakan untuk mengetahui dan menampung berbagai permasalah sosial serta peluang untuk pengembangan daerah pedesaan. Metode ini dilakukan dengan memobilisasikan sumberdaya alam dan manusia melalui partisipasi masyarakat desa dengan teknik-teknik tertentu.
} 
diperoleh adalah kondisi fisik lingkungan desa, pola usaha tani, teknik budidaya dan pengolahan lahan, potensi dan masalah yang ada, serta informasi tentang sosial ekonomi dan budaya serta kebiasaan masyarakat. Teknik sketsa kebun merupakan teknik PRA untuk menggali informasi melalui penggambaran keadaan kebun pada lokasi-lokasi tertentu dan mencakup berbagai aspek kegiatan pengelolaan lahan, jenis tanam serta pola tanamnya. Informasi yang diperoleh adalah pola tanam, luas lahan, jenis tanaman, praktek konservasi, pendapatan dari kebun, teknologi pengelolaan lahan, dan harapan masyarakat dalam mengelola lahan. Teknik analisis mata pencaharian berupa kegiatan diskusi untuk mengenali dan menganalisa keadaan kehidupan masyarakat dari aspek mata pencaharian. Dengan teknik ini akan diketahui informasi tentang jenis-jenis mata pencaharian dan pendapatan masyarakat. Teknik wawancara semi terstruktur merupakan teknik penggalian informasi berupa tanya jawab yang sistematis, bersifat semi terbuka tetapi pembicaraannya dibatasi oleh topik yang telah ditentukan.

Data dan informasi yang dikumpulkan, baik data primer ataupun data sekunder, kemudian dianalisis dengan analisis deskriptif kualitatif dan kuantitatif. Data yang di analisis secara deskriptif kualitatif dan kuantitatif meliputi kondisi wilayah, letak, luas, sistem pengolahan lahan, kondisi pemukiman, pendidikan, pendapatan masyarakat, dan kegiatan ekonomi masyarakat.

\section{HASIL DAN PEMBAHASAN \\ Peta Desa Air Lanang}

Desa Air Lanang merupakan salah satu desa yang berbatasan langsung dengan Hutan Lindung Bukit Daun, yang termasuk ke dalam wilayah Kecamatan Curup, Kabupaten Rejang Lebong, Propinsi Bengkulu. Batas-batas wilayah desa ini, di sebelah Utara berbatasan dengan Desa Tanjung Dalam, sebelah selatan berbatasan dengan Bukit Marbau, sebelah Barat berbatasan dengan Hutan Lindung Bukit Daun dan sebelah Timur berbatasan dengan Desa Tanjung Alam (Senoaji, 2007). Hutan Lindung Bukit Daun merupakan salah satu hutan lindung di Propinsi Bengkulu yang mempunyai peranan penting dalam pengaturan tata air tanah dan perlindungan lingkungan yakni merupakan sumber mata air dan daerah tangkapan air beberapa sungai besar seperti Sungai Musi, Sungai Ketahun, dan Sungai Seblat (Bapedalda Propinsi Bengkulu, 2006).

Luas wilayah Desa Air Lanang secara keseluruhan adalah 289,25 ha. Sebagian besar wilayahnya berupa perbukitan dengan kemiringan di atas $30 \%$. Rayes (2006) menyatakan bahwa kemiringan lahan merupakan salah satu yang berperan penting dalam menentukan kemampuan suatu lahan. Idealnya, kemiringan lahan

7 Rayes (2006) "Metode Inventarisasi Sumber Daya Lahan". Kelas kemampuan lahan adalah pengelompokan lahan ke dalam satuan-satuan khusus menurut kemampuannya untuk penggunaan intensif dan perlakuan yang diperlukan untuk dapat digunakan secara terus menerus. Faktor yang mempengaruhi kelas kemampuan lahan adalah : kelerangan yang berhubungan dengan erosi, iklim, dan tanah. Lahan dengan kelerengan $25 \%$ - $65 \%$, untuk dijadikan lahan pertanian perlu perlakukan tindakan konservasi seperti pembuatan teras, pembuatan saluran drainase atau pergiliran tanaman 
yang sesuai untuk kegiatan pertanian adalah di bawah $25 \%$. Untuk kemiringan lahan $25 \%-65 \%$ yang akan digunakan untuk lahan pertanian, perlu perlakukan tindakan konservasi, sedangkan kemiringan > $65 \%$ sesuai untuk kawasan perlindungan. Ditinjau dari bentang lahannya sebagian besar lahan di desa ini berupa lahan perkebunan.

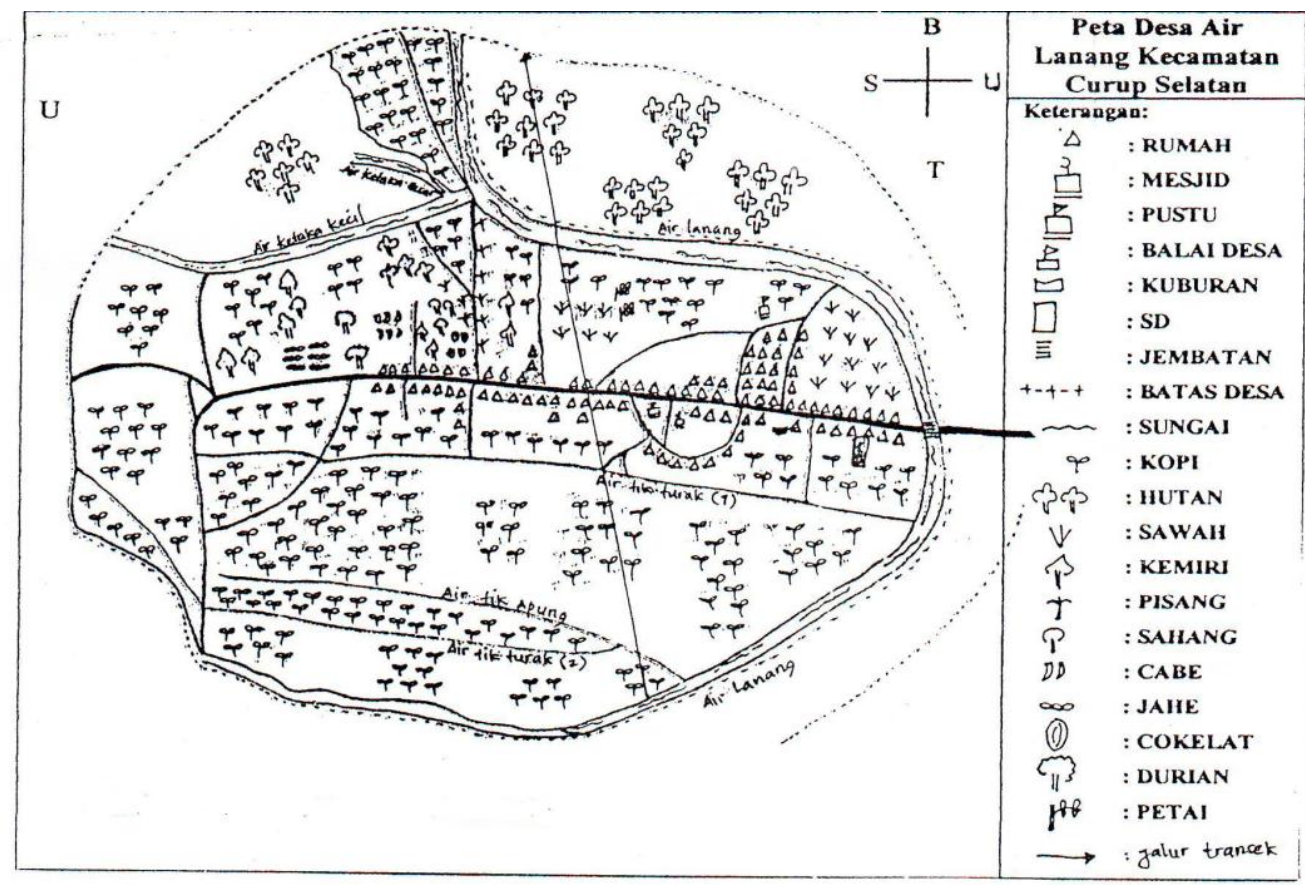

Gambar 1. Sketsa Peta Desa Air Lanang, Bengkulu

Desa Air Lanang terdiri dari 3 dusun yaitu Dusun 1, Dusun 2, dan Dusun 3, dengan pusat pemerintah desanya di Dusun 2. Luas lahan pertanian mencapai $97,1 \%$ dari luas kawasan desa atau sekitar 281 hektar, luas pemukiman dan fasilitas desa lainnya hanya sekitar 8,25 hektar. Pola pemukiman masyarakatnya memanjang sejajar dengan jalan desa, paling banyak hanya sekitar 4 lapis rumah dari jalan desa. Budidaya lahan pertanian yaag dikembangkan oleh masyarakat desa ini adalah perkebunan dan pertanian sawah. Jenis tanaman perkebunan yang ditanam di desa ini adalah kopi, merica, cabe, jahe, coklat, dan berbagai jenis tanaman sayuran. Tanaman kopi merupakan tanaman utama masyarakat. Selain menanam tanaman pertanian dan perkebunan, masyarakat juga menanam

penutup tanah. Lahan dengan kelerengan $>65 \%$ tidak sesuai untuk kegiatan pertanian harus didiamkan secara alami, peruntukannya untuk hutan lindung atau tempat rekreasi alam. 
berbagai jenis pohon di lahannya seperti pohon kemiri, durian, petai, mangga, rambutan, dan kayu bawang. Bibit-bibit tanaman pohon itu berasal dari bantuan program hutan kemasyarakatan yang gulirkan mulai tahun 1999. Lokasi sawah terletak di pinggir Sungai Air Lanang yang sekaligus sebagai sumber pengairan sawahnya. Luas sawah di desa ini hanya sekitar 10 hektar; budaya pertanian sawah bukan merupakan budaya utama pekerjaan masyarakat desa ini; budaya utama mereka adalah berkebun kopi di lahannya (Pemerintah Desa Air Lanang, 2007).

Tabel 1. Tata Guna lahan di Desa Air Lanang

\begin{tabular}{clcc}
\hline No & \multicolumn{1}{c}{ Penggunaan } & Luas (ha) & Persentase (\%) \\
\hline 1 & Pemukiman & 3 & 1,0 \\
2 & Fasilitas Desa & 5,25 & 1,9 \\
3 & Lahan pertanian (kebun dan sawah) & 281 & 97,1 \\
\hline & Jumlah & 289.25 & 100 \\
\hline
\end{tabular}

Sumber : Pemerintah Desa Air Lanang, 2007

Sistem pemerintahan di Desa Air Lanang sama seperti sistem pemerintahan yang ada di desa-desa lainnya di propinsi Bengkulu. Desa Air Lanang dipimpin oleh seorang kepala desa yang dipilih oleh rakyat berdasarkan suara terbanyak dan dibantu oleh Badan Perwakilan Desa dan lembaga adat. Penduduknya berasal dari Suku Rejang, Suku Lembak dan Suku Serawai, yang merupakan suku asli di Propinsi Bengkulu. Seperti halnya di desa-desa di Kabupaten Rejang Lebong, masyarakat Suku Rejang mendominasi penduduk di desa ini.

Kesehatan masyarakat di desa-desa sekitar hutan lindung Bukit Daun pada dasarnya dipengaruhi oleh beberapa hal di antaranya kualitas pelayanan yang dilakukan oleh petugas kesehatan, ketersediaan obat, kebiasaan hidup sehat, sanitasi lingkungan, dan makanan yang dikonsumsi (Senoaji, 2005). Penyakit yang menduduki peringkat pertama di Desa Air Lanang ini adalah infeksi saluran pernafasan atas (Pemerintah Desa Air Lanang, 2007).

Jarak rumah ke hutan lindung menjadi salah satu faktor yang mempengaruhi perilaku masyarakat dalam pemanfaatan hutannya. Simon (2001) membagi jarak rumah ke kawasan hutan menjadi tiga strata, yaitu :

1. Daerah interface, dinamakan stratum A, yaitu areal hutan yang letaknya berbatasan langsung dengan pemukiman. Biasanya jaraknya kurang dari $3 \mathrm{~km}$.

2. Daerah peralihan, yaitu daerah hutan yang jaraknya agak jauh dari pemukiman, dinamakan stratum B. Jarak berkisar antara 3-5 km.

3. Daerah remote, dinamakan stratum $\mathrm{C}$, yaitu kawasan hutan yang jaraknya dari pemukiman penduduk lebih dari $5 \mathrm{~km}$. 
Jarak rata-rata dari desa ke kebun masyarakat di kawasan hutan lindung Bukit Daun adalah 2,6 km, yang termasuk ke dalam katagori daerah interface. Berdasarkan pembagian jarak rumah ke hutan menurut Simon (2001), $46 \%$ dari responden termasuk ke dalam stratum A yaitu jarak antara rumah dan hutan lindungnya kurang dari $3 \mathrm{~km}$; sedangkan sisanya $54 \%$ termasuk ke dalam stratum B, yakni jarak antara hutan lindung dan pemukiman $3-5 \mathrm{~km}$. Senoaji (2001) menjelaskan bahwa jarak dari rumah atau pemukiman ke hutan lindung berpengaruh terhadap luas perambahan hutan yang dilakukan oleh masyarakat. Semakin dekat jarak rumah dengan hutan lindung akan semakin besar luas lahan hutan yang dibuka di dalam kawasan hutan, karena akan lebih memudahkan aksesibilitas untuk keluar masuk hutan lindung tersebut. Kondisi jalan yang menuju hutan lindung di Desa Air Lanang berupa jalan setapak yang tidak memungkinkan dilalui oleh kendaraan roda dua atau roda empat, sehingga masyarakat yang membuka kebun di kawasan hutan lindung aksesnya hanya dengan berjalan kaki menyusuri jalan hutan.

\section{Sosial Ekonomi Masyarakat}

Penduduk Desa Air Lanang berjumlah 285 kepala keluarga (KK) yang terdiri dari 1.460 jiwa, 721 jiwa laki-laki dan 739 jiwa perempuan. Berdasarkan tingkatan umur, penduduk terbanyak di Desa Air Lanang adalah berada pada umur 26-30 tahun sebanyak 157 jiwa $(10,75 \%)$, sedangkan jumlah terendah berada pada kelompok umur 51-55 tahun sebanyak 80 jiwa dengan persentase 5,48\%. Menurut Mantra (2000) berdasarkan angkatan kerja, kelompok umur 15-50 tahun adalah usia produktif, yakni selang usia yang termasuk kelompok umur pekerja. Dengan demikian penduduk Desa Air Lanang didominasi oleh penduduk yang berusia produktif $(66,03 \%)$, yang berpotensi untuk selalu bekerja, dalam hal ini memperluas lahan garapannya.

Mata pencaharian pokok masyarakat Desa Air Lanang adalah petani. Penduduk yang menjadi petani sebanyak 281 KK $(98,6 \%)$ selebihnya adalah pengawai negeri sebanyak $4 \mathrm{KK}(1,4 \%)$. Sebagian dari mereka berprofesi ganda, yakni petani dan pekerjaan lain seperti peternak sebanyak $12 \mathrm{KK}$, pedagang $12 \mathrm{KK}$, buruh $35 \mathrm{KK}$. Jenis pekerjaan penduduk akan berhubungan erat dengan tekanan masyarakat ke dalam hutan. Senoaji dan Ridwan (2006) menjelaskan bahwa masyarakat desa hutan yang jenis pekerjaannya petani cenderung akan meningkatkan nilai koofesien tekanan penduduknya ${ }^{8}$ ke dalam kawasan hutan; hal ini disebabkan karena semakin terbatasnya lahan pertanian akibat pertambahan

\footnotetext{
8 Soemarwoto (1992) dan (1996) "Analisa mengenai Dampak Lingkungan" dan "Indonesia dalam Kancah Isu Lingkungan Global. Koofesien tekanan penduduk menunjukan besarnya gaya atau kekuatan yang mendorong masyarakat untuk memperluas lahannya ke dalam kawasan hutan. Semakin tinggi nilai koofesien tekanan (TP) semakin tinggi tekanan masyarakat ke dalam kawasan untuk membuka lahan atau kebun. Nilai koofesien tekanan penduduk sama dengan dua berarti ada dorongan penduduk untuk memperluas lahan garapannya menjadi dua kali lebih luas dari lahan pertanian yang tersedia.
} 
jumlah penduduk. Selanjutnya Simon (2000) menjelaskan bahwa salah satu faktor rusaknya hutan adalah peningkatan jumlah penduduk yang tinggi.

Luas lahan pertanian dan atau perkebunan di Desa Air Lanang ini 281 hektar dengan 285 kepala keluarga sehingga rata-rata kepemilikan lahan pertanian adalah sekitar 0,9 hektar per kepala keluarga. Menurut Senoaji dan Ridwan (2006), batasan hidup layak di desa sekitar hutan lindung Bukit Daun dengan komoditas kopi adalah 0,3 hektar/jiwa atau 1,5 hektar per kepala keluarga ${ }^{9}$. Dengan demikian, masyarakat di desa ini kekurangan lahan pertanian; sehingga untuk memperluas lahan pertaniannya mereka membuka hutan lindung yang ada di sekeliling pemukimannya.

Tabel 2. Karakteristik Responden Berdasarkan Letak Lahan Garapan

\begin{tabular}{cccc}
\hline \multirow{2}{*}{ No } & \multirow{2}{*}{ Letak Lahan } & \multicolumn{2}{c}{ Jumlah Responden } \\
\cline { 3 - 4 } & Di dalam kawasan hutan & Jumlah KK & Persen (\%) \\
\hline 1 & Di luar kawasan hutan & 10 & $33,33 \%$ \\
3 & Di dalam dan Luar kawasan hutan & 10 & $33,33 \%$ \\
\hline \multirow{2}{*}{ Jumlah } & 30 & $33,34 \%$ \\
\hline
\end{tabular}

Sumber : Olahan Data Primer, 2008

Hasil penelitian pada tabel 2 menunjukkan bahwa 66,7 \% responden masyarakat desa membuka kebun di dalam kawasan hutan, baik yang hanya membuka di dalam hutan ataupun di dalam dan di luar hutan. Rata-rata luas lahan garapan masyarakat di desa ini setiap kepala keluarga adalah 2,5 hektar; dengan demikian jika dirata-ratakan berdasarkan jumlah petani dan luas lahan garapan serta kepemilikan lahannya, maka setiap kepala keluarga petani di desa ini memiliki luas lahan di dalam kawasan hutan sekitar 1,6 hektar. Jika setiap kepala keluarga membuka lahan kebun di hutan seluas 1,6 hektar, maka lahan hutan yang terbuka di desa ini telah mencapai 456 hektar, dan akan terus bertambah sejalan dengan meningkatnya jumlah penduduk.

Berdasarkan letak lokasinya, kebun masyarakat dibagi menjadi dua kelompok, yakni kebun yang terletak di dalam kawasan hutan lindung dan di luar kawasan hutan lindung. Perlakuan untuk kebunnya, baik yang di dalam atau di luar hutan, relatif sama. Pada setiap kebunnya dibangun pondok atau gubuk untuk beristirahat dan lapangan terbuka sekitar $50-100 \mathrm{~m}^{2}$ untuk menjemur hasil kopinya. Bagi petani di desa ini, kebun dan pondoknya merupakan rumah kedua

\footnotetext{
${ }^{9}$ Senoaji dan Ridwan (2006). "Studi Identifikasi Tekanan Penduduk ke Dalam Hutan di Daerah Interaksi Hutan Lindung Bukit Daun Kabupaten Kepahiang Propinsi Bengkulu". Luas lahan yang dibutuhkan untuk hidup layak di Desa Kelilik dan Desa Kandang (desa sekitar hutan lindung Bukit Daun) dengan komoditas utamanya kopi adalah 0,31 hektar per jiwa atau 1,5 hektar per kepala keluarga.
} 
bagi mereka. Aktivitas harian mereka berada di kebun, terlebih-lebih pada saat musim panen, mereka tidak pulang ke desanya. Kegiatan sehari-harinya memanen kopi dan menjemur sampai kopinya siap dijual. Kebun yang terdapat di luar kawasan hutan umumnya hanya ditanami tanaman pokok kopi dan tanaman pengisi lainnya seperti jahe, lada, dan tanaman sayuran. Pada lahan ini tidak ditemukan jenis tanaman pohon karena jenis tanaman pohon akan menaungi tanaman kopinya. Untuk kebun yang berada di dalam kawasan hutan, sesuai arahan dari program hutan kemasyarakatan, selain ditanami tanaman kopi, juga ditanami tanaman pohon sebagai penguat tanah. Di dua lokasi kebun ini, tanaman kopi merupakan tanaman pokok masyarakat sebagai sumber pendapatan utamanya; jenis tanaman lainnya seperti jahe, lada, dan tanaman sayuran hanya sebagai sumber penghasilan tambahan untuk memenuhi kebutuhan hidup seharihari.

Jarak tanam kopi di kebun luar kawasan hutan adalah $3 \times 1$ meter, sehingga dalam 1 hektar terdapat 3.000 tanaman kopi. Untuk kebun yang berada di dalam kawasan hutan lindung, pola tanamnya menerapkan sistem agroforestri, yakni mengkombinasikan tanaman kopi dengan tanaman kehutanan, seperti pinang, durian, kemiri, petai, dan kayu bawang, dengan jarak tanam pohonnya $6 \times 6 \mathrm{~m}$. Sehingga dalam 1 hektarnya terdapat 270 tanaman pohon dan 2.730 tanaman kopi. Sama halnya dengan kebun di luar kawasan hutan, di kebun inipun ditanami tanaman pengisi lainnya seperti cabe, jahe, dan sayuran.
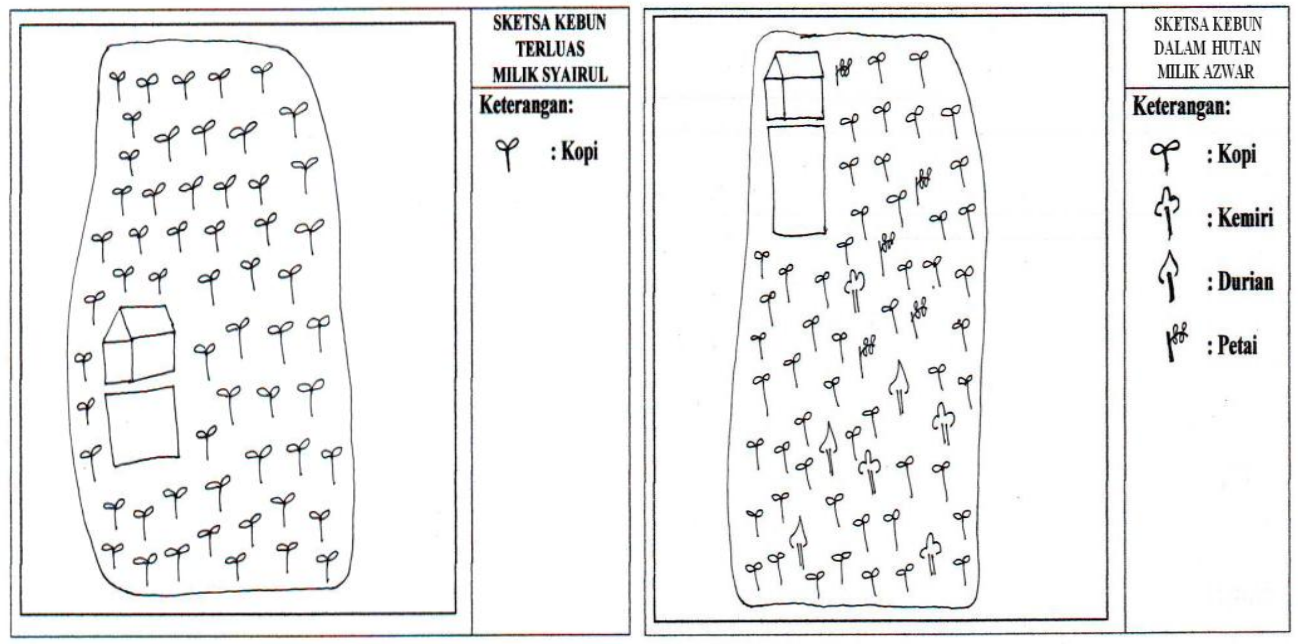

Gambar 2. Sketsa Kebun di dalam dan di luar Kawasan Hutan Lindung

Hasil komoditas utama petani di Desa Air Lanang adalah kopi. Hasil pertanian lainnya umumnya digunakan sendiri untuk pemenuhan kebutuhan hidup seharihari. Oleh karena itu pendapatan petani di Desa Air Lanang sangat ditentukan oleh 
produksi kopi ${ }^{10}$ dan harga jual kopi (Edwar, 2003). Produksi rata-rata kopi per tahun adalah $500 \mathrm{~kg}$ per hektar. Senoaji (2009) menjelaskan bahwa rata-rata besarnya pendapatan pendapatan masyarakat dari kebun di dalam kawasan hutan sebesar Rp. 9.875.000,00 per tahun per kepala keluarga, dan dari luar kawasan hutan Rp. 8.812.500,00 . Rata-rata jumlah jiwa per kepala keluarga di desa penelitian adalah 5,3 ; sehingga pendapatan per kapita masyarakatnya sekitar Rp. 1.863.200,00 dari lahan hutan dan Rp. 1.662.735,00 dari lahan di luar hutan. Nilai pendapatan ini didasarkan kepada harga kopi sebesar Rp. 15.000/kg. Pada harga kopi sebesar ini, kehidupan masyarakatnya dapat dikatagorikan cukup sejahtera.

Menurut masyarakat, sejak adanya krisis moneter tahun 1997 pendapatannya tidak tetap, kadang meningkat drastis kadang pula turun drastis. Sebagai gambaran pada tahun 2007 - 2008, harga jual kopi bervariasi mulai dari Rp. 4.000 - 17.000 per kilogram. Jika dibandingkan dengan indikator kesejahteraan Sayogyo ${ }^{11}$, bahwa batas garis kemiskinan di pedesaan adalah $320 \mathrm{~kg}$ beras; maka penduduk di Desa Air Lanang secara umum dikatagorikan hidup cukup sejahtera. Namun jika harga kopi di bawah Rp. 6000 per kilogram, masyarakatnya termasuk kedalam golongan penduduk miskin.

Secara umum masyarakat yang tinggal di sekitar hutan memiliki tingkat pendidikan yang rendah. Hal ini disebabkan tingkat perekonomian masyarakatnya rendah dan tidak adanya fasilitas pendidikan yang lebih lanjut di daerahnya. Tingkat pendidikan masyarakat sekitar hutan di Desa Air Lanang relatif rendah. Masyarakat yang tidak sekolah 364 jiwa (24.93\%); pendidikan SD sebanyak 416 jiwa (28.49\%); tingkat pendidikan menengah berjumlah 310 jiwa $(21,23 \%)$; dan perguruan tinggi berjumlah 2 jiwa (0,14\%). Menurut teori human capital ${ }^{12}$, kualitas sumber daya manusia selain ditentukan oleh tingkat kesehatan juga ditentukan oleh tingkat pendidikan. Pendidikan dipandang tidak hanya dapat menambah pengetahuan tetapi juga dapat meningkatkan keterampilan tenaga kerja sehingga akan meningkatkan produktivitas. Peningkatan produktivitas dapat meningkatkan pertumbuhan ekonomi dan meningkatkan penghasilan dan kesejahteraan

\footnotetext{
${ }^{10}$ Kopi merupakan komoditas utama masyarakat di desa hutan di Propinsi Bengkulu. Tanaman lain seperti jahe, sahang, sayuran hanya untuk pemenuhan keperluan sehari-hari dan bukan prioritas untuk dijual, dan hanya ditanam pada saat tanaman kopinya masih kecil oleh sebagian responden. Oleh karena itu dalam penelitian ini besarnya pendapatan petani ditentukan oleh komoditas kopi yang ditanam oleh semua responden.

${ }_{11}$ Sayogyo. (1977). "Golongan Miskin di Indonesia." Pustaka 2/II. Bandung. Golongan miskin pedesaan diukur berdasarkan banyaknya pengeluaran perkapita pertahun yang setara dengan 240 $320 \mathrm{~kg}$ beras. Harga beras di lokasi penelitian Rp. 6.000 per $\mathrm{kg}$, batas golongan miskinnya adalah pendapatan per kapita sebesar Rp. 1.920.000

${ }^{12}$ Lisnawati (2007) "Aspek Ekonomi dalam Pendidikan" Educare. Teori human capita/mengasumsikan bahwa pendidikan formal merupakan instrumen terpenting untuk menghasilkan masyarakat yang memiliki produktivitas yang tinggi. Investasi dalam pendidikan merupakan suatu investasi dalam meningkatkan produktivitas masyarakat.
} 
penduduk. Selain keterampilan, tingkat pendidikan juga mempunyai pengaruh terhadap pola pikir masyarakat.

Budaya masyarakat memegang peranan penting dalam membentuk perilaku masyarakat dalam memanfaatkan hutan lindung (Senoaji, 2005). Masyarakat di sekitar Hutan Lindung Bukit Daun pada umumnya adalah Suku Rejang. Dalam memanfaatkan lahan di sekitarnya, budaya menanam kopi merupakan budaya tanam yang paling dominan. Hampir semua masyarakat di desa-desa ini mempunyai kebun kopi. Sejalan dengan bertambahnya jumlah penduduk, lahan pertanian yang tersedia menjadi terbatas; sedangkan budaya untuk memiliki kebun kopi tetap menjadi tuntutan masyarakat, terutama bagi para pemuda yang akan segera menikah. Cara yang paling mudah untuk memiliki kebun adalah dengan membuka kebun kopi di kawasan hutan lindung. Di beberapa tempat, luasnya kebun kopi masih menjadi tolak ukur tingginya derajat seseorang. Budaya seperti ini menjadi faktor penyebab tingginya kerusakan hutan lindung (Senoaji, 2007).

Beberapa responden mengakui bahwa perbuatan membuka kebun di hutan lindung adalah perbuatan yang melanggar aturan. Namun karena desakan kebutuhan ekonomi dan terbatasnya lahan di luar kawasan hutan, terpaksa mereka membuka kebun di hutan lindung. Pak Madihi, seorang pegawai Dinas Kehutanan Propinsi Bengkulu, menjelaskan bahwa sebelum reformasi (di bawah tahun 1998) operasi pengamanan hutan dilakukan dengan tindakan destrukti, seperti penghancuran semua kebun atau ladang yang ditemui di dalam hutan. Namun semenjak tahun 1999, dengan adanya program hutan kemasyarakatan, operasi penghancuran kebun di hutan sudah tidak dilakukan lagi; yang dikedepankan adalah pemberdayaan masyarakat di dalam kawasan hutan dengan berbagai aturan yang disepakati bersama. Program hutan kemasyarakatan ini timbul karena pendekatan destruktif yang dilakukan pemerintah selama ini tidak berdampak nyata di lapangan; kawasan hutan yang rusak akibat perambahan semakin bertambah banyak.

\section{Pengelolalaan Hutan oleh Masyarakat}

Hutan lindung adalah kawasan hutan yang mempunyai fungsi pokok sebagai perlindungan sistem penyangga kehidupan untuk mengatur tata air, mencegah banjir, mengendalikan erosi, mencegah intrusi air laut, dan memelihara kesuburan tanah. Dalam Peraturan Pemerintah No. 6 tahun 2007 dijelaskan bahwa kawasan hutan lindung dapat dimanfaatkan untuk berbagai macam kegiatan yaitu berupa pemanfaatan kawasan, pemanfaatan jasa lingkungan, dan pemungutan hasil hutan bukan kayu.

Pemanfaatan kawasan ${ }^{13}$ dapat berupa : usaha budidaya tanaman obat, budidaya tanaman hias, budidaya jamur, budidaya perlebahan, budidaya

\footnotetext{
13 Dalam PP No. 6 tahun 2007 dijelaskan bahwa masyarakat yang akan memanfaatkan lahan di kawasan hutan untuk berbagai kepentingan di luar kehutanan, harus meminta ijin pada instansi yang
} 
penangkaran satwa liar, dan budidaya sarang burung walet. Pemanfaatan jasa lingkungan dapat berupa : usaha wisata alam, usaha olah raga tantangan, usaha pemanfaatan air, usaha perdagangan karbon, dan usaha penyelamatan hutan dan lingkungan. Pemungutan hasil hutan bukan kayu pada hutan lindung dapat berupa : mengambil rotan, mengambil madu, mengambil buah, dan perburuan satwa liar yang tidak dilindungi. Teknik perlakuan dalam memanfatkan hutan lindung dalam pemanfaatan kawasan harus memenuhi persyaratan : tidak menebang pohon, pengolahan tanah menggunakan teknik yang tidak menimbulkan erosi, tidak menggunakan pestisida dan insektisida, tidak menggunakan peralatan mekanis, tidak dilakukan pada kelerengan di atas $25 \%{ }^{14}$.

Implementasi dari kegiatan yang disebutkan di atas menjelaskan kegiatan atau perilaku yang boleh dilakukan oleh masyarakat di dalam kawasan hutan lindung. Beberapa perilaku masyarakat kadang-kadang bertentangan dengan aturan yang berlaku, seperti menebang pohon untuk mengambil kayu pertukangan, menebang pohon untuk mengambil kayu bakar, membuka hutan untuk areal ladang/kebun, dan berburu binatang yang dilindungi. Perilaku tersebut sebagian tidak disadari oleh responden bahwa kegiatan itu bertentangan dengan aturan yang berlaku. Mereka beranggapan bahwa boleh mengelola hutan lindung setelah adanya program hutan masyarakat yang digulirkan pemerintah.

Pemerintah, melalui Departemen Kehutanan, telah mengupayakan pengelolaan hutan di desa ini dengan konsep hutan kemasyarakatan, yakni konsep pengelolaan hutan lindung yang memberikan kesempatan kepada masyarakat sekitar desa untuk memanfaatkan lahan hutannya dengan memperhitungkan aspek pemilihan jenis tanaman dan jarak tanam. Jenis tanaman yang ditanam adalah tanaman kopi dan tanaman pertanian masyarakat dengan tanaman kehutanan multi purpose tree species (MPTS) atau tanaman kayu-kayuan seperti : kayu bawang, surian, durian, pete, pinang, dan kemiri, dengan menggunakan jarak tanam pohon tertentu seperti $6 \times 6$ meter.

Program hutan kemasyarakatan di desa ini mulai digulirkan sejak tahun 1999 mulai dari pembentukan kelembagaan, pelatihan, penyiapan bibit, penanaman, pendampingan, dan monitoring evaluasi. Hasil wawancara dengan masyarakat dan pengamatan langsung di lapangan, secara fisik persentase penanaman tananaman MPTS yang dilakukan cukup berhasil, hanya saja tanaman kemiri atau pinang yang ditanam di lahannya sudah mulai ditebangi oleh masyarakat. Alasan mereka pohon-pohon tersebut mengganggu pertumbuhan kopi. Tujuan akhir dari program hutan kemasyarakatan sebenarnya adalah menggantikan tanaman kopi dengan tanaman kehutanan. Harapannya, jika tanaman kehutanannya sudah

mengurusi bidang kehutanan. Di Kabupaten Kepahiang dan Rejang Lebong, Bengkulu instansinya adalah Dinas Kehutanan dan Perkebunan kabupaten.

${ }^{14}$ Wilayah dalam hutan lindung dengan kelerengan $>25 \%$ tidak boleh digunakan untuk kepentingan pemanfaatan kawasan, pemanaatan jasa lingkungan, dan pemungutan hasil hutan. Di luar kawasan hutan, seperti wilayah Desa Air Lanang, ketentuan ini tidak berlaku, sehingga cukup banyak kelerengan $>25 \%$ yang digunakan masyarakat untuk kegiatan budidaya tanaman pertanian. 
menghasilkan dan tanaman kopinya sudah ternaungi, petani akan mengurangi aktifitasnya terhadap kopi dan beralih kepada budidaya tanaman kehutanan. Sehingga nantinya lahan kebun hutannya dipenuhi oleh tanaman-tanaman kayu keras yang lebih banyak memberikan fungsi perlindungan lingkungan dibanding kopi. Namun setelah sekitar sembilan tahun penanaman dan pertumbuhan tanaman pohon telah baik, petani tetap mengutamakan tanaman kopinya dan bahkan mulai menebangi tanaman hutannya. Berhasilkah program hutan kemasyarakatan ? ternyata budaya berkebun kopi memegang peranan penting dalam aspek pengelolaan hutan seperti ini.

Perilaku masyarakat dalam pemanfaatan hutan berupa aktivitas masyarakat dalam membuka lahan, mengambil kayu bakar, dan menebang pohon di dalam kawasan hutan lindung (Senoaji, 2005). Perilaku yang pertama adalah membuka lahan. Sistem pembukaan lahan yang dilakukan oleh masyarakat adalah dengan cara menebang pohon dan menebas semak belukar dan membakarnya. Setelah lahan bersih baru dilakukan penanaman. Jenis tanaman yang ditanam umumnya adalah kopi dan tanaman MPTS seperti durian, kemiri, petai, dan lainnya. Perilaku masyarakat yang kedua adalah menebang pohon sebagai sumber kayu pertukangan, baik untuk dijual atau pemenuhan kebutuhan sendiri. Perilaku masyarakat yang ketiga adalah pengambilan kayu bakar. Pengambilan kayu bakar disini adalah kegiatan mengambil kayu di hutan lindung dengan menebang pohonpohon yang masih kecil.

Perilaku masyarakat tersebut sebenarnya bertentangan dengan peraturan yang berlaku tentang pemanfaatan hutan lindung. Hanya saja semua perilaku dan kegiatan yang dilakukan masyarakat semata-mata untuk memenuhi kebutuhan hidupnya karena semakin terbatasnya lahan pertanian. Pemerintah saat ini sedang merancang suatu strategi pengelolaan hutan yang bisa mengakomodir fungsi lingkungan dari hutan lindung dan sekaligus fungsi ekonomis bagi masyarakat sekitarnya.

\section{SIMPULAN}

Masyarakat desa di sekitar hutan lindung Bukit Daun, Rejang Lebong, Bengkulu umumnya adalah masyarakat yang bermatapencarian petani, berpendidikan rendah, sederhana, dan kehidupannya tergantung pada kawasan hutan yang ada disekelilingnya. Sejalan dengan pertambahan penduduk, kepemilikan lahan pertanian setiap keluarga menurun dan kebutuhan akan pangan meningkat. Masyarakat telah mulai mengalami kekurangan lahan pertanian. Untuk mencukupinya, sebagian masyarakat merambah hutan lindung di sekitar pemukimannya untuk dijadikan kebun. Sekitar $66,67 \%$ masyarakat responden membuka kebun di kawasan hutan lindung. Mereka menanam tanaman kopi sebagai tanaman utama dan tanaman lainnya seperti jahe, sahang, dan sayuran sebagai tanaman selingan untuk memenuhi kebutuhan sehari-hari.

Kawasan hutan lindung Bukit Daun sebenarnya merupakan kawasan hutan yang berfungsi sebagai perlindungan lingkungan, yakni pengatur tata air dan 
menjaga kesuburan tanah, serta sebagai sistem penyangga kehidupan. Akan tetapi dengan adanya tekanan tinggi dari masyarakat yang menjadikan hutan lindung sebagai kebun, pemerintah menggulirkan program kehutanan sosial mulai tahun 1999. Program ini hakekatnya adalah melibatkan masyarakat dalam pengelolaan hutan yang mengarah kepada keseimbangan fungsi hutan sebagai perlindungan lingkungan dan sumber ekonomi bagi masyarakat. Di Desa Air Lanang, program kehutanan masyarakat ini belum dapat dikatakan berhasil. Harapan berubahnya tegakan kebun kopi di hutan lindung menjadi tegakan tanaman MPTS belum tercapai. Masyarakat masih tetap menanami kopi di kebun hutannya bahkan mulai menebangi tanaman MPTS-nya yang ditanam sembilan tahun yang lalu.

\section{DAFTAR PUSTAKA}

Arikunto. 2003. Manajemen Penelitian. Penerbit Rineka Cipta. Jakarta.

Edwar, M. 2003. Tinjauan dan Kontribusi Agroforest Berbasis Tanaman Kopi terhadap Pendapatan Masyarakat Desa Hutan (Studi Kasus di Kabupaten Rejang Lebong Propinsi Bengkulu). Thesis Program Pacsasarjana Universitas Gadjah mada. Yogyakarta. (tidak dipublikasi).

Daniel, M., Darmawati, Nieldalina. 2006. Partisipatory Rural Appraisal, Pendekatan Efektif Mendukung Penerapan Penyuluhan Partisipatif dalam Upaya Percepatan Pembangunan Pertanian. Bumi Aksara. Jakarta.

Departemen Kehutanan, 2002. Informasi Umum Kehutanan. Jakarta.

Lisnawati, C. 2007. Aspek Ekonomi dalam Pendidikan. Educare. Jurnal Penelitian dan Budaya, Volume 4 nomor 2. Bandung.

Mantra, IB. 2000. Demografi Umum. Pustaka Pelajar. Yogyakarta.

2008. Filsafat Penelitian dan Metode Penelitian Sosial. Pustaka Pelajar. Yogyakarta.

Nur Hidayat dan Suparno. 2002. Pengembangan Kelompok Masyarakat Produktif Mandiri Berbasis Pembangunan Kehutanan. Pusat Penyuluhan Departemen Kehutanan. Jakarta.

Pemerintah Desa Air Lanang. 2007. Monografi Desa Air Lanang Tahun 2007. Kecamatan Curup Selatan. Kabupaten Rejang Lebong. 
Pemerintah Propinsi Bengkulu, 2008. Laporan Status Lingkungan Hidup Propinsi Bengkulu Tahun 2008. Bengkulu.

Pemerintah Republik Indonesia, 1999. Undang-Undang No. 41 tahun 1999 tentang Kehutanan. Jakarta.

2007. Peraturan Pemerintah No. 6 tahun 2007 tanggal 8 Januari 2007. tentang Tata Hutan dan Rencana Pengelolaan Hutan serta Pemanfaatan hutan. Jakarta.

Rayes, M.F. 2006. Metode Inventarisasi Sumber Daya Lahan. Penerbit Andi. Yogyakarta.

Sayogyo. 1977. Golongan Miskin di Indonesia. Pustaka 2/II. Bandung

Senoaji, G. 2001. Studi Daya Dukung Lingkungan Desa-desa Sekitar Hutan ditinjau dari Aspek Ekologi, Ekonomi dan kelestarian sumberdaya hutan. Laporan Penelitian DIKS Universitas Bengkulu.

2005. Perilaku Masyarakat Desa Sekitar Hutan ditinjau dari Aspek Sosial, Ekonomi, dan Budaya di Kawasan Hutan Lindung Bukit Daun, Kabupaten Kepahiang, Bengkulu. Laporan Penelitian Dasar Dirjen DIKTI. Jakarta.

-----------., dan Ridwan. 2006. Studi Identifikasi Tekanan Penduduk ke Dalam Hutan di Daerah Interaksi Hutan Lindung Bukit Daun Kabupaten Kepahiang Propinsi Bengkulu. Laporan Penelitian Dosen Muda Dirjen DIKTI. Jakarta.

2007. Bagaimana Masyarakat Sekitar Hutan Lindung Bukit Daun Memanajemen Kawasan Hutannya di Bengkulu. Media Ekonomi, Jurnal Ekonomi, Manajemen dan Akutansi , Vol VI. No. 1 Mei 2007, p 18 - 23.

2009. Kontribusi Hutan Lindung terhadap Pendapatan Masyarakat Desa di sekitarnya. Studi Kasus di Desa Air Lanang, Bengkulu. Jurnal Manuasia dan Lingkungan, Volume 16 No. 1 Bulan Maret 2009. Yogyakarta.

Simon, H. 2000. Hutan Jati dan Kemakmuran. Problematika dan Strategi Pemecahan. BIGRAF Publishing. Yogyakarta.

--------. 2001. Pengelolaan Hutan Bersama Rakyat (Cooperative Forest Management) Teori dan Aplikasi pada hutan Jati di Jawa. Bigraf Publishing. Yogyakarta. 
Soemarwoto, O. 1992. Indonesia dalam Kancah Isu Lingkungan Global. Gramedia Pustaka Utama. Jakarta.

1996. Analisa Mengenai Dampak Lingkungan. Gadjah Mada University Press. Yogyakarta.

Steinlin, H. 1988. Menuju Kelestarian hutan. Seri Studi Pertanian Kerjasama Jerman dan Indonesia. Yayasan Obor Indonesia. Jakarta.

Subaktini, D., Andi C., Nana H., Teguh S. 2002. Kajian Aspek Sosial, Budaya, dan Ekonomi Pengelolaan Hutan Rakyat Di Kabupaten Wonogiri. Prosiding Ekspose BP2TPDAS-IBB Surakarta- Wonogiri, 1 Oktober 2002. 